\title{
Evidence-based non-skeletal actions of vitamin D
}

\author{
Evidências das ações não esqueléticas da vitamina D
}

Patricia Muszkat', Marilia Brasilio Rodrigues Camargo', Luiz Henrique Maciel Griz², Marise Lazaretti-Castro'

${ }^{1}$ Divisão de Endocrinologia, Unidade de Metabolismo Ósseo e Mineral, Escola Paulista de Medicina, Universidade Federal de São Paulo (Unifesp/EPM), São Paulo, SP, Brasil 2 Departamento de Medicina, Divisão de Endocrinologia, Hospital Agamenon Magalhães, Sistema Único de Saúde (SUS), Universidade de Pernambuco (UPE), Recife, PE, Brasil
Correspondence to:

Marise Lazaretti-Castro

Rua Borges Lagoa, 800

04038-001 - São Paulo, SP, Brasil

lazaretti.castro@unifesp.br

Received on Jan/15/2010

Accepted on Feb/9/2010

\section{SUMMARY}

Vitamin $\mathrm{D}$ is a major regulator of mineral homeostasis through its action in the kidney, intestine, bone and parathyroid glands. On these tissues, its active form, calcitriol, acts by binding to a specific nuclear receptor that belongs to the steroid/thyroid hormone receptor family. This receptor, however, has also been identified in several additional human tissues. So, apart from its traditional actions related to calcium, vitamin D and its synthetic analogs are being increasingly recognized for their anti-proliferative, pro-differentiative and immunomodulatory activities. Low levels of vitamin D have been linked to many chronic diseases. Decreased muscle function and increased fall risk in elderly people; prostate, breast and colorectal cancers; diabetes mellitus; and other health problems have been associated to low circulating levels of 25-hydroxyvitamin D. This paper presents an overview of the available scientific evidence for the non-calcemic actions of vitamin D in humans. Arq Bras Endocrinol Metab. 2010;54(2):110-7

Keywords

Vitamin D; metabolism; deficiency; cancer; muscle strength; calcium

\section{SUMÁRIO}

A vitamina $D$ é um importante regulador da homeostase mineral por meio de sua ação nos rins, no intestino, nos ossos e nas glândulas paratireoides. Nesses tecidos, sua forma ativa, o calcitriol, atua ligando-se a um receptor nuclear específico, pertencente à família de receptores dos hormônios esteroides e tireoidianos. Contudo, esse receptor também foi identificado em outros tecidos humanos. Assim, além de suas ações tradicionais, relacionadas ao metabolismo do cálcio, a vitamina $D$ e análogos sintéticos estão, cada vez mais, sendo reconhecidos por seus efeitos antiproliferativos, pró-diferenciação e imunomodulatórios. Baixas concentrações séricas de vitamina $D$ têm sido associadas a várias doenças crônicas. Redução da função muscular e aumento do risco de quedas em idosos; câncer de próstata, mama e colorretal; diabetes melito; e outros problemas de saúde têm sido associados a concentrações circulantes baixas de 25-hidroxivitamina $D$. Este trabalho apresenta uma visão geral sobre as evidências científicas disponíveis das ações não calcêmicas da vitamina D em humanos. Arq Bras Endocrinol Metab. 2010;54(2):110-7

\section{Descritores}

Vitamina D; metabolismo; deficiência; câncer; força muscular; cálcio

\section{INTRODUCTION}

$\mathrm{V}$ Titamin $\mathrm{D}_{3}$ is truly a prohormone rather than a vitamin. It is produced in the skin through ultraviolet irradiation of 7-dehydrocholesterol (Figure 1). Some nutrients like fatty fish, eggs and dairy products also contain vitamin $\mathrm{D}_{3}$, but they are not consumed as fre- quently as necessary for an essential dietary factor. Our main source of vitamin $\mathrm{D}_{3}$ is endogenous production (1). The adequate requirement of vitamin $\mathrm{D}$ may be achieved if the exposition of the skin with solar ultraviolet radiation occurs in a regular and safe manner. This correlation between sun exposure and plasma concentrations of 25-hydroxyvitamin D (25OHD) becomes 
apparent when evaluated over the months of the year. There is a clear seasonal variation in these levels in the elderly and even in young people $(2,3)$. In an elderly population living in Sao Paulo, Brazil, 25OHD levels after summer are twice as high as those observed after winter, at $67.2 \mathrm{nmol} / \mathrm{L}$ and $29.1 \mathrm{nmol} / \mathrm{L}$, respectively (2). In young people living in this same city we also found a seasonal variation but of lower magnitude; their summer 25OHD levels were approximately $30 \%$ higher than winter concentrations (3).

Thanks to migratory movements in the world population and the behavioral changes witnessed in the last century, body sun expositions have become rare, and vitamin $\mathrm{D}$ deficiency has reached epidemic rates worldwide (4). Even in sunny countries such as Brazil data are impressive: $71.2 \%$ of the institutionalized and $55.8 \%$ of the free-living elderly from the city of Sao Paulo $\left(23^{\circ} \mathrm{S}\right)$ had very low levels of $25 \mathrm{OHD}$ $(<50 \mathrm{nmol} / \mathrm{L}$ and $<20 \mathrm{ng} / \mathrm{mL})$, with almost the same proportion of secondary hyperparathyroidism, $61.7 \%$ and $54.0 \%$, respectively (Figure 2) (5). For practical reasons we should keep in mind that an exposure time of 10 minutes three times per week of unprotected head and arms would be adequate to prevent vitamin $\mathrm{D}$ deficiency $(4,6,7)$.

A meta-analysis of randomized, controlled trials published in 2007 reviewed the association between vitamin $\mathrm{D}$ supplementation and total mortality. The mean daily dose of vitamin $\mathrm{D}$ supplements ranged from $400 \mathrm{IU}$ to $833 \mathrm{IU}$. The authors concluded that the intake of ordinary doses of vitamin D supplements seems to be associated with decreases in total mortality. The relationship between baseline vitamin $\mathrm{D}$ status, dose of vitamin D supplements and total mortality rates remains to be investigated (8).

\section{VITAMIN D METABOLISM}

Vitamin D is denominated a secosteroid because one of the rings of its cyclopentanoperhydrophenanthrene structure has a broken carbon-carbon bond (Figure 1). Vitamin $\mathrm{D}_{3}$ undergoes two hydroxylation reactions, a hepatic 25-hydroxylation and a renal $1-\alpha$-hydroxylation, to produce the active hormone $1 \alpha, 25$ dihydroxyvitamin $\mathrm{D}_{3}\left[1,25(\mathrm{OH})_{2} \mathrm{D}_{3}\right]$. The steroid hormone $1,25(\mathrm{OH})_{2} \mathrm{D}_{3}$ interacts with a single vitamin $\mathrm{D}$ receptor in the cell nucleus to exert its biological functions. It is well known that the active metabolite
$1,25(\mathrm{OH})_{2} \mathrm{D}_{3}$ plays an important role in bone mineral metabolism and health, however, $1,25(\mathrm{OH})_{2} \mathrm{D}_{3}$ has a wide range of non-calcemic actions that are also useful for promoting optimal health $(7,9,10)$.

Vitamin D receptor (VDR) is a phosphoprotein member of the nuclear receptor superfamily that functions as a ligand-dependent transcription factor. VDR binds as a heterodimer with retinoid $\mathrm{X}$ receptor (RXR) to hexameric repeats, characterized as vitamin $\mathrm{D}$ responsive elements present in the regulatory region of many target genes such as osteocalcin, osteopontin, calbindin-D28K, calbindin-D9K, TGF- $\beta 2$ and vitamin D 24-hydroxylase. Many factors such as glucocorticoids, estrogens, retinoids, cell proliferation rate and transformation can modulate VDR levels (11). The molecular cloning of VDR and the identification of its widespread expression in human tissues led researchers to suspect that the vitamin D endocrine system has additional physiological functions beyond calcium homeostasis. Vitamin D and VDR have been shown to play important roles in the immune, cardiovascular and reproductive systems and in hair growth. The few cells or tissues that have low or absent VDR expression include red blood cells, mature striated muscle cells and some differentiated brain cells, such as Purkinje cells of the cerebellum (10). An important step in studying the functions of $1,25(\mathrm{OH})_{2} \mathrm{D}_{3}$ was the generation of VDR- and $1 \alpha$-hydroxylase-null mice (12). Table 1 summarizes features of nontraditional $1,25(\mathrm{OH})_{2} \mathrm{D}_{3}$ target tissues in VDR-null mice.

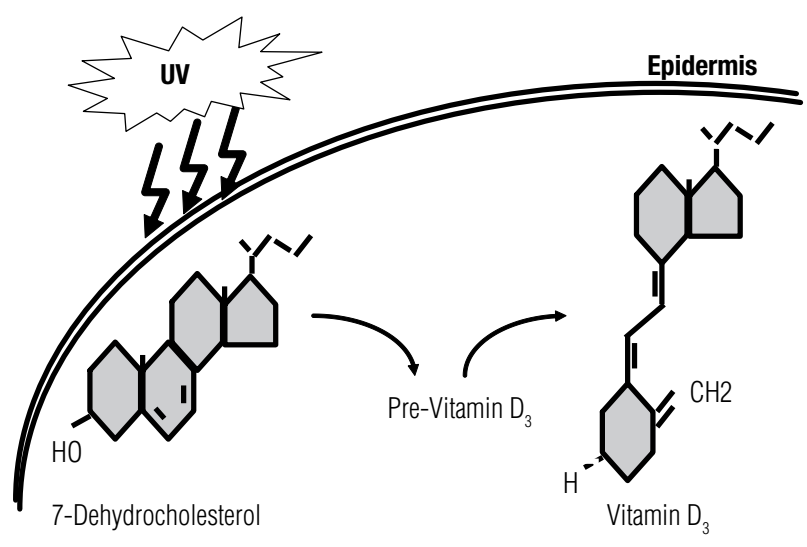

Figure 1. Photobiosynthesis of vitamin $D_{3}$ in skin. 
250HD (nmol/L)

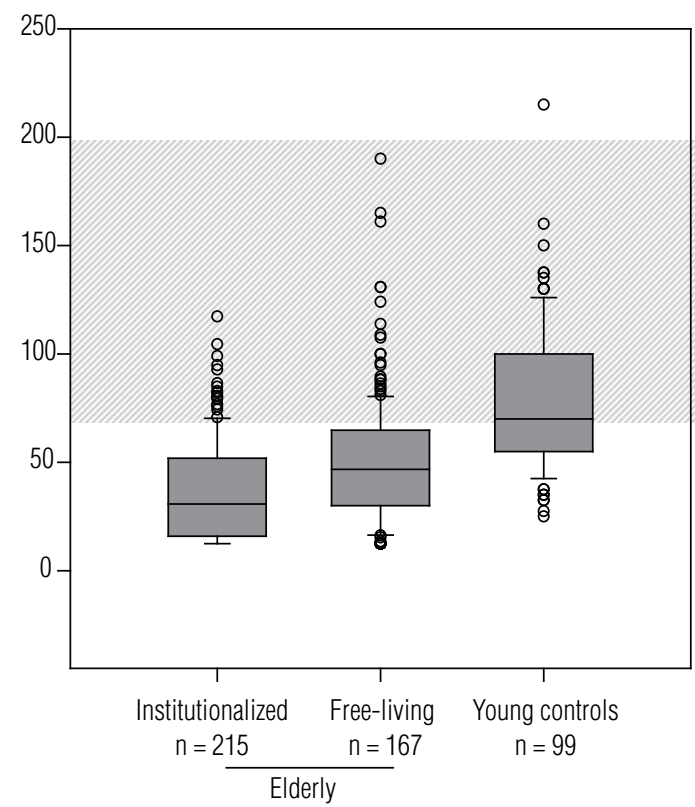

PTH $(p g / m L)$

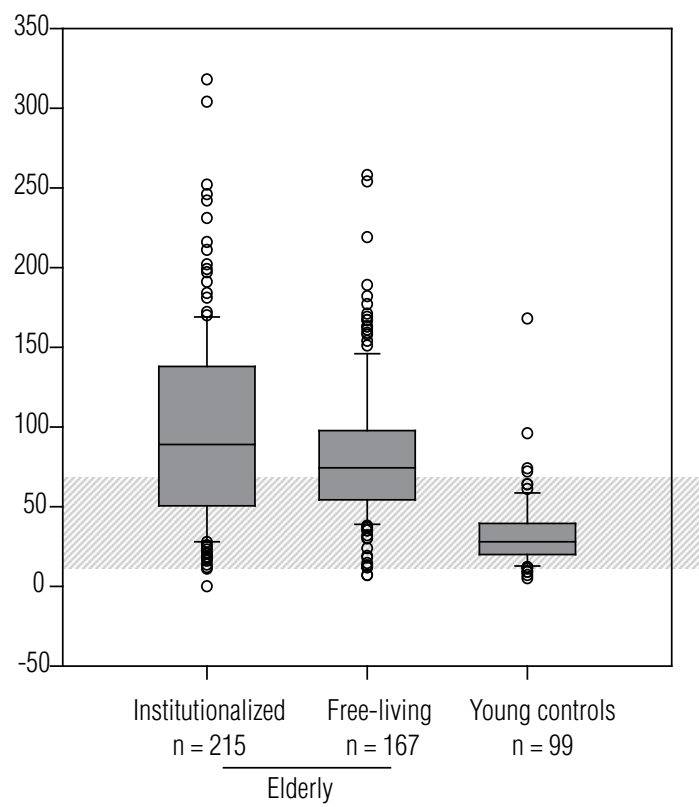

Figure 2. Concentrations of 25 hydroxyvitamin $\mathrm{D}(250 \mathrm{HD})$ and parathyroid hormone (PTH) in three different populations living in the city of Sao Paulo, Brazil $\left(23^{\circ} \mathrm{S}\right)$ : institutionalized and free-living elderly people, compared to young normal controls (5). The marked boxes define the normal range values for both hormones.

Table 1. Non-classical 1 $\alpha, 25$-dihydroxyvitamin $\mathrm{D}_{3}$ target tissues in VDRnull mice models

\begin{tabular}{|c|c|}
\hline Tissue & Feature \\
\hline Skin & $\begin{array}{l}\text { Alopecia } \\
\text { Abnormal hair cycling } \\
\text { Anti-proliferative and pro-differentiative effect on } \\
\text { keratinocytes }\end{array}$ \\
\hline Muscle & $\begin{array}{l}\text { Smaller muscle fibers } \\
\text { Persistent expression of early markers of myogenic } \\
\text { differentiation }\end{array}$ \\
\hline $\begin{array}{l}\text { Cardiovascular } \\
\text { system }\end{array}$ & $\begin{array}{l}\text { High renin hypertension } \\
\text { Cardiac hypertrophy }\end{array}$ \\
\hline Immune system & $\begin{array}{l}\text { Impaired macrophage function } \\
\text { Abnormal Th1 macrophage-induced formation } \\
\text { Increased number of immature dendritic cells } \\
\text { Predisposition to autoimmune diseases such as type } 1 \text { diabetes } \\
\text { Decreased monocytic differentiation and antibacterial activity } \\
\text { of monocytes }\end{array}$ \\
\hline $\begin{array}{l}\text { Pancreas } \beta \\
\text { cells }\end{array}$ & $\begin{array}{l}\text { Normal glucose tolerance or mild glucose intolerance } \\
\text { Is a target tissue with discrepancy between effects of the } \\
\text { vitamin D ligand and the VDR itself }\end{array}$ \\
\hline Brain & Abnormal behavior, especially muscle and motor behavior \\
\hline $\begin{array}{l}\text { Cell } \\
\text { proliferation/ } \\
\text { Cancer }\end{array}$ & $\begin{array}{l}\text { Hyperproliferation of colonic cells } \\
\text { Dysregulated growth of alveolar and ductal mammary gland cells } \\
\text { Enhanced susceptibility to chemocarcinogen-induced } \\
\text { leukemia }\end{array}$ \\
\hline $\begin{array}{l}\text { Reproductive } \\
\text { system }\end{array}$ & $\begin{array}{l}\text { Uterine hypoplasia } \\
\text { Impaired ovarian folliculogenesis } \\
\text { Male infertility }\end{array}$ \\
\hline
\end{tabular}

\section{VITAMIN D DEFICIENCY AND NON-SKELETAL DISEASES}

Low levels of vitamin D have been linked to many chronic conditions and diseases. Epidemiological findings, genetic studies and clinical trials have been published and have shown strong evidence of this linkage $(13,14)$. A great number of in vitro studies give support to these epidemiological and clinical findings. $1,25(\mathrm{OH})_{2} \mathrm{D}_{3}$ has potent anti-proliferative and pro-differentiative effects in a wide variety of cell types, and its effects have been tested in different types of cancer cells such as prostate, breast, ovarian, colorectal, squamous, and leukemia cells. The variety of target genes identified through these studies reflects the pleiotropic action of $1,25(\mathrm{OH})_{2} \mathrm{D}_{3}$. Common cellular processes targeted by $1,25(\mathrm{OH})_{2} \mathrm{D}_{3}$ in different cancer cell lines include cell-cycle progression, apoptosis, cellular adhesion, oxidative stress, immune function and steroid metabolism (15). This review mentions some of the most important diseases.

\section{Breast cancer}

Epidemiologic studies have shown an inverse relationship between sun exposure and a higher incidence of breast cancer (12). A recent meta-analysis of vitamin D and the prevention of breast cancer found a $45 \%$ de- 
crease in breast cancer risk for those in the highest quartile of circulating $25 \mathrm{OHD}(60 \mathrm{nmol} / \mathrm{L})$ compared to those with the lowest level. No relationship was found between the level of circulating $1,25(\mathrm{OH})_{2} \mathrm{D}_{3}$ and breast cancer (16).

VDR is expressed in mammary tissue and breast cancer cells which are potential targets for hormone action. Besides having anti-proliferative properties, vitamin D might also reduce the invasiveness of cancer cells and act as an anti-angiogenesis agent (12). Another piece of evidence that links vitamin $\mathrm{D}$ and breast cancer is the fact that the chromosomal region $20 \mathrm{ql} 3.2$, which contains 24-hydroxylase is amplified in breast cancer (12). Because 24-hydroxylase is involved in $1,25(\mathrm{OH})_{2} \mathrm{D}_{3}$ degradation, its amplification may lead to decreased serum levels of vitamin $\mathrm{D}$ providing an environment conducive for cell growth in the absence of vitamin $\mathrm{D}$-mediated growth control. The exact mechanism underlying the growth inhibitory actions of vitamin D in breast cancer is not clear, but data support that the effect of vitamin D may involve growth arrest at the G0/Gl stage, cell apoptosis or disruption of estrogen and other growth factor-mediated cell survival signals and angiogenesis (12). All of these anti-tumoral features suggest that the properties of vitamin D and VDR could be explored for therapeutic purposes in breast cancer, and different $1,25(\mathrm{OH})_{2} \mathrm{D}_{3}$ analogs with potent anti-proliferative but lesser hyper-calcemic effects are being developed and tested for clinical use (9).

\section{Colon cancer}

Epidemiological studies have suggested the involvement of vitamin $\mathrm{D}$ in the pathogenesis of colorectal tumors. An inverse association has been reported between vitamin D levels and colon cancer incidence (12). Increased VDR protein was found in colonic tumors more than in their normal counterparts (12). Apart from possessing VDR, colonic cells also posses the ability to synthesize $1,25(\mathrm{OH})_{2} \mathrm{D}_{3}$ from 25-hydroxyvitamin $\mathrm{D}_{3}$ by the local action of 1 (-hydroxylase activity. Despite all of these facts, a recent randomized, double-blind, placebo-controlled trial involving 36,282 women from the Women's Health Initiative found that daily supplementation of calcium $(1,000 \mathrm{mg})$ with vitamin D (400 IU) for seven years had no effect on the incidence of colorectal cancer among postmenopausal women. On the other hand, an intake of $2000 \mathrm{UI} /$ day of vitamin D may reduce by $27 \%$ the incidence of colorectal cancer in North America $(17,18)$.

\section{Prostate cancer}

Laboratory in vitro studies have demonstrated that $1,25(\mathrm{OH})_{2} \mathrm{D}_{3}$ and its synthetic analogs inhibit the proliferation of prostate cancer cell lines (12). Epidemiological studies have also shown that increased exposure to UV light may be protective against prostate cancer, but this finding has been conflicting and requires further investigation to support the association. Polymorphisms of the VDR gene that affect the receptor binding of $1,25(\mathrm{OH})_{2} \mathrm{D}_{3}$ may modify vitamin D's biological activity and confer different susceptibility to prostate cancer. In a recent meta-analysis performed by Yin and cols. (19), 36 publications on the association of Taql, Apal, Bsml, Fokl and CDx2 single nucleotide polymorphisms in susceptibility to prostate cancer were identified. The authors suggested that Taq $1 \mathrm{t}$ and Bsm $\mathrm{l}$ $\mathrm{B}$ alleles were associated with reduced prostate cancer risk among all study populations, whereas the Fok $1 \mathrm{f}$ allele was associated with increased cancer risk among Caucasian populations (19). According to recent evidence, $25 \mathrm{OHD}$ may play a role in the regulation of cell proliferation in the prostate. It is mainly acting directly through the VDR, but it may also partially act through its lalpha-hydroxylation in the prostate. A lack of vitamin D action may also be due to an altered metabolism or vitamin D resistance. Vitamin D resistance might be brought up by several mechanisms, and the local metabolism of hormonal vitamin $\mathrm{D}$ seems to play an important role in the development and progression of prostate cancer $(20)$.

\section{Leukemia}

$1,25(\mathrm{OH}) 2 \mathrm{D} 3$ plays a role in the regulation of the immune system. Cells of the monocyte/macrophage lineage possess receptors for $1,25(\mathrm{OH})_{2} \mathrm{D}_{3}$ regardless of their activation stage. Further, $1,25(\mathrm{OH})_{2} \mathrm{D}_{3}$ promotes the differentiation of monocyte precursors towards monocyte/macrophages and enhances monocyte function in antigen presentation. In addition, $1,25(\mathrm{OH})_{2} \mathrm{D}_{3}$ modulates cytokine production by lymphocytes (21).

Although one of the first described non-classical vitamin $\mathrm{D}$ actions was its ability to promote differentiation and block proliferation of murine myeloid leukemia, clinical trials up to this point have failed to obtain good results in clinical management when they use $1,25(\mathrm{OH})_{2} \mathrm{D}_{3}$ and analogs to treat myelodysplastic syndromes and myeloid leukemia (22). 


\section{Multiple sclerosis}

Epidemiological studies have related an increase of multiple sclerosis with increasing geographical latitude. Clinical studies have shown that vitamin D levels are lower among patients with multiple sclerosis. There is also evidence that UV light and calcitriol reduce the symptoms of multiple sclerosis (23).

\section{Type 1 diabetes}

Vitamin D deficiency is largely described in diabetes mellitus type 1 (TIDM) patients from different origins $(24,25)$. Vitamin D deficiency has been associated with an increased risk of TIDM. Glycemic control and insulin resistance are improved when vitamin D deficiency is corrected and calcium supplementation is adequate. Studies have also shown an increase in the incidence of TIDM when vitamin D deficiency was present in the first month of life in children $(12,23)$. VDR gene polymorphisms may be associated with the risk of developing TIDM, but reports have been conflicting $(26,27)$. Because $1,25(\mathrm{OH})_{2} \mathrm{D}_{3}$ has very well established in vitro effects on insulin secretion and on immunological response, there are some suggestions that vitamin D deficiency may play a role in the development of type 1 diabetes, although this hypothesis is still to be confirmed.

\section{Type 2 diabetes}

Several reports have demonstrated a role of vitamin $\mathrm{D}$ in the functional regulation of pancreatic beta cells (28). The identification of receptors for $1,25(\mathrm{OH})_{2} \mathrm{D}_{3}(29)$ and the expression of $1 \alpha$-hydroxylase enzyme in pancreatic beta cells (30) support a role of vitamin D in pancreatic beta cells. Vitamin D deficiency inhibits pancreatic secretion of insulin (31) and is associated with glucose intolerance (32). Vitamin D is essential for insulin release (33), while vitamin D supplementation restores insulin secretion (34). In peripheral insulin target tissues vitamin D may enhance insulin sensitivity by stimulating the expression of insulin receptors (35).

A large cross-sectional survey showed a significant inverse association between serum 25OHD and diabetes prevalence (36). Recent prospective analysis from an English cohort reported inverse associations between baseline serum 25OHD and future glycemic status and insulin resistance (37), and a Finnish cohort study showed an inverse association between baseline serum $25 \mathrm{OHD}$ and the 17 -year risk of type 2 diabetes (38). The Nurse's Health Study (39) demonstrated that women with an average vitamin $\mathrm{D}$ daily intake $>800$ UI had a $33 \%$ lower risk of the incidence of type 2 diabetes compared to an intake $<200$ UI.

In spite of these observational data supporting the role of vitamin $\mathrm{D}$ in the development of type 2 diabetes, it is unlikely that vitamin $\mathrm{D}$ deficiency would be a major cause of this disease. Further cohort studies are required to test the hypothesis that vitamin D deficiency is a cause of diabetes, and we clearly need more evidence that vitamin D supplementation reduces the risk of diabetes.

\section{Muscle function}

Several studies have shown that vitamin D metabolites affect muscle cell metabolism through various pathways: by mediating gene transcription, through rapid pathways not involving DNA synthesis and by the allelic variant of the VDR (40). Both in animal models and in humans, a VDR has been found in skeletal muscle cells that specifically binds $1,25(\mathrm{OH})_{2} \mathrm{D}_{3}$. Vitamin D supplementation induces rapid changes in calcium metabolism of the muscle cell that cannot be explained by a slow genetic pathway. Evidence indicates that $1,25(\mathrm{OH})_{2} \mathrm{D}_{3}$, possibly through a vitamin $\mathrm{D}$ membrane receptor, acts directly on the muscle cell membrane. Upon $1,25(\mathrm{OH})_{2} \mathrm{D}_{3}$ binding, several interacting second-messenger pathways were activated in the muscle cell, resulting in enhanced calcium uptake. Muscle strength also appears to be influenced by the genotype of the VDR in the muscle cell. Various cases have been described in which prolonged vitamin $\mathrm{D}$ deficiency was associated with severe muscle weakness, often leading to a marked disability that improved with vitamin D supplementation. However, few studies have been conducted in which muscle strength was objectively quantified in relation to vitamin $\mathrm{D}$ status $(10,41-43)$. In a prospective, double-blind, placebo-controlled, randomized trial with Brazilian institutionalized elderly people we showed that a 6-month vitamin D supplementation significantly improved lower limb muscle strength in the absence of any regular physical exercise practice (Figure 3) (44).

Vitamin D deficiency has also been related to an increase in the incidence of falls. A recent systematic review including eight prospective, double-blind, randomized, controlled studies suggests that vitamin D in doses of 700 to $1000 \mathrm{UI} /$ day may reduce the risk of an elderly person falling by $19 \%$. Doses of supplemental vitamin D less than 700 IU or serum 25-hydroxyvitamin $\mathrm{D}$ concentrations than $60 \mathrm{nmol} / \mathrm{L}$ may not reduce the risk of falling among older individuals (45). 


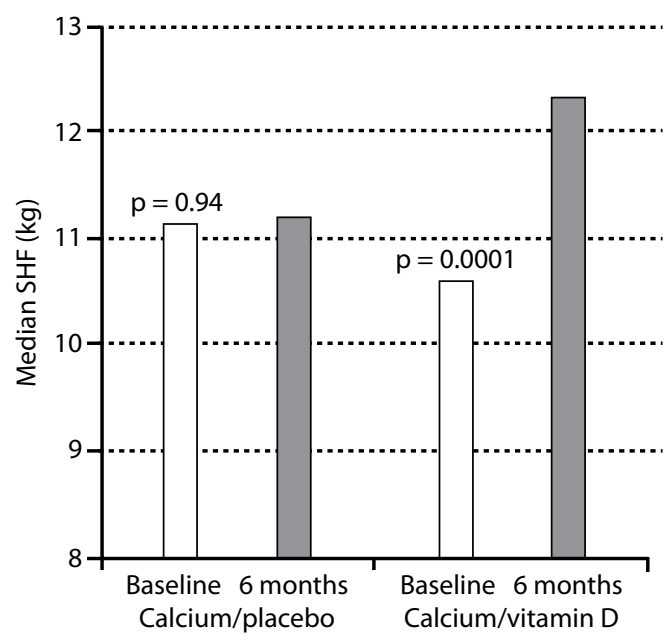

B

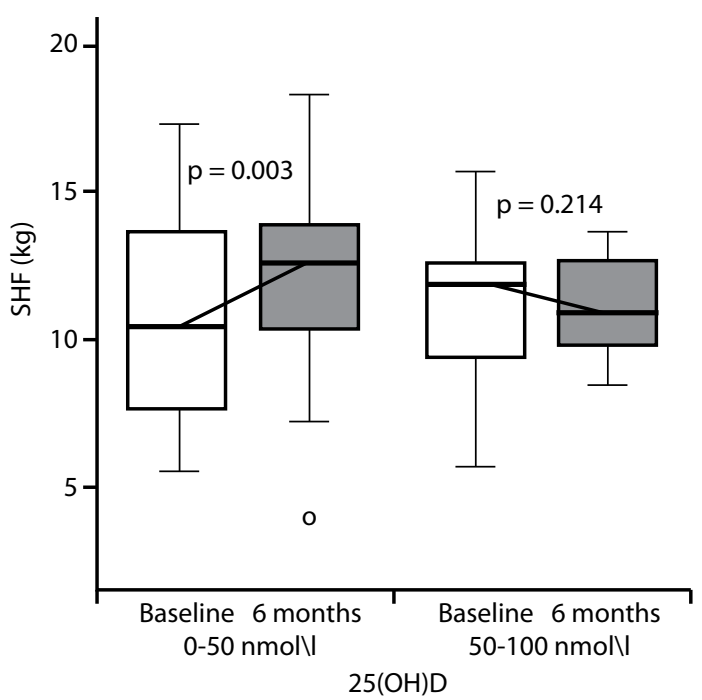

Figure 3. Evaluation of the Strength of Hip Flexors (SFH) after six-month vitamin D replacement in institutionalized elderly. (A) Shows the significant increment in SFH observed in the group that received vitamin $\mathrm{D}_{3}$ treatment (average of $3600 \mathrm{UI} /$ day), which was not seen in the placebo group. (B) Demonstrates that the SFH increment was seen only in those who had lower levels of $250 \mathrm{HD}$ levels at baseline $(<50 \mathrm{nmol} / \mathrm{L})(43)$.

\section{Cardiovascular disease}

Recent evidence suggests that vitamin D may play a role in mortality risk. The major circulating form of vitamin $\mathrm{D}, 25 \mathrm{OHD}$, has been associated with all causes of mortality in individuals with end-stage renal disease and coronary artery disease and even in the general population (46). Further evidence suggests that vitamin D supplementation may lower mortality. Several mechanisms can be considered in the relationship between vitamin $\mathrm{D}$ and cardiovascular disease (CVD). The first is the effect on the renin-angiotensin system (RAS) (47). As vitamin $\mathrm{D}$ inhibits renin activity, vitamin $\mathrm{D}$ deficiency activates RAS. Vitamin D also has protective effects on CVD by suppressing cardiac hypertrophy. As inflammation is involved in atherosclerosis, which is CVD's basic clinical condition, vitamin $\mathrm{D}$ possibly suppresses CVD events through its anti-inflammatory function. This indicates that vitamin $\mathrm{D}$ is influential in the inhibition of CVD events from different pathways (48).

\section{Psychiatric and neurologic disorders}

Vitamin D deficiency is common in older adults and has been implicated with psychiatric and neurological disorders such as depression, multiple sclerosis, fibromyalgia, schizophrenia and Parkinson's disease. Depression has incidentally been related to altered levels of $25 \mathrm{OHD}$, but this relation has never been studied systematically. Murphy and Wagner (49) evaluated, in an integrative review, studies that investigated the association between vitamin $\mathrm{D}$ and mood disorders in women. The authors found a significant association between mood disorders and low 25OHD levels in four of six studies, indicating that some biochemical mechanism may exist between these two variables. In a crosssectional study to investigate the relationship among vitamin $\mathrm{D}$ status and cognitive performance, mood and physical performance in older adults, the authors showed that vitamin D deficiency was associated with low mood and impairment in two of four evaluations of cognitive performance (50). A large prospective study found that high circulating levels of vitamin $\mathrm{D}$ were associated with a lower risk of multiple sclerosis (5l). Besides that, a large population-based cohort study demonstrated an association between depression status and severity with decreased circulating levels of $25 \mathrm{OHD}$ and increased serum PTH levels in older individuals (52). These associations warrant further studies to confirm the influence of vitamin status on psychiatric and neurological disorders.

\section{Microbial infections}

The innate immunity plays a critical role in human defense. The innate immune response includes recogni- 
tion of microbial invasion and production of antimicrobial peptides such as defensins and cathelicidins (10). The discovery of VDR expression in activated inflammatory cells signalized the importance of vitamin D and the active form $1,25(\mathrm{OH})_{2} \mathrm{D}_{3}$ in the immune function (53). Exposing monocytes and macrophages to $1,25(\mathrm{OH})_{2} \mathrm{D}_{3}$ improves their chemotactic and phagocytic capacity, features that are indispensable for their tumor cell cytotoxicity and microbacterial activity (10). The current vitamin D-dependent antimicrobial immunity model proposes that when a pathogen is detected by its respective Toll-like receptor (pattern-recognition receptor), VDR and $1 \alpha$-hydroxylase gene expression are induced $(10,53)$. This leads to $1 \alpha$-hydroxylation of $25 \mathrm{OHD}$, which is taken up from the blood, and subsequent binding of $1,25(\mathrm{OH})_{2} \mathrm{D}_{3}$ to the VDR. The cathelecidin gene is activated and its respective protein is synthesized for use against the pathogen that has been engulfed in the phagosome of the macrophage (53).

Elevated $1,25(\mathrm{OH})_{2} \mathrm{D}_{3}$ and hypercalcemia have been associated with active pulmonary tuberculosis, and epidemiological studies have demonstrated that lower serum concentration of $25 \mathrm{OHD}$ correlates with increased susceptibility to tuberculosis (54). The beneficial effects of vitamin D supplementation on treatment of tuberculosis have been studied in randomized clinical trials, but conflicting results have been reported (53). Further clinical trials are needed to elucidate the potential therapeutic applications of vitamin D and its synthetic analogs against tuberculosis and other infectious diseases (53).

\section{CONCLUSION}

In the last twenty years, vitamin $\mathrm{D}$ and its non-classical actions have taken an important place in the clinical scenario. After this discovery, many epidemiological and interventional studies have proved the benefits of vitamin D sufficiency status in promoting good health. The search for vitamin D synthetic analogs without calcemic activity will allow the promising clinical use of these hormone analogs in the prevention and treatment of chronic diseases, like cancer, diabetes, muscle weakness and autoimmune diseases.

Acknowledgment: Marise Lazaretti-Castro is a consultant at Sanofi-Aventis and Novartis and participates as Principal Investigator in clinical research trials supported by Merck, Sharp \& Dohme, Eli Lilly and Pfizer. Patricia Muszkat participates as subinvestigator in clinical research trials supported by Merck, Sharp \& Dohme, Eli Lilly and Pfizer.
Disclosure: no potential conflict of interest relevant to this article was reported.

\section{REFERENCES}

1. Norman AW. From vitamin $D$ to hormone D: fundamentals of the vitamin $D$ endocrine system essential for good health. Am J Clin Nutr. 2008;88(suppl):491S-9S.

2. Saraiva GL, Cendoroglo MS, Ramos LR, Araújo LM, Vieira JG, Kunii I, et al. Influence of ultraviolet radiation on the production of 25-hydroxyvitamin $D$ in the elderly population in the city of Sao Paulo (23 degrees 34'S), Brazil. Osteoporos Int. 2005;16(12):1649-54.

3. Maeda SS, Kunii IS, Hayashi L, Lazaretti-Castro M. The effect of sun exposure on 25-hydroxyvitamin D concentrations in young healthy subjects living in the city of Sao Paulo, Brazil. Braz J Med Biol Res. 2007;40(12):1653-9. [Epub 2007 Oct 29]

4. Lips P. Vitamin D deficiency and secondary hyperparathyroidism in the elderly: consequences for bone loss and fractures and therapeutic implications. Endocr Rev. 2001;22:477-501.

5. Saraiva GL, Cendoroglo MS, Ramos LR, Araújo LM, Vieira JG, Maeda SS, et al. Prevalence of vitamin D deficiency, insufficiency and secondary hyperparathyroidism in the elderly inpatients and living in the community of the city of Sao Paulo, Brazil. Arq Bras Endocrinol Metabol. 2007;51(3):437-42.

6. Lucas RM, Repacholi MH, McMichael AJ. Is the current public health message on UV exposure correct? Bull World Health Organ. 2006;84:485-91.

7. Dusso AS, Brown AJ, Slatopolsky E. Vitamin D. Am J Physiol. 2005;289:F8-28.

8. Autier P, Gandini S. Vitamin D supplementation and total mortality. Arch Intern Med. 2007;167(16):1730-7.

9. Bortman P, Folgueira MA, Katayama ML, Snitcovsky IM, Brentani MM. Antiproliferative effects of 1,25-dihydroxyvitamin D3 on breast cells: a mini review. Braz J Med Biol Res. 2002;35(1):1-9.

10. Bouillon R, Carmeliet G, Verlinden L, van Etten E, Verstuyf A, Luderer HF, et al. Vitamin $D$ and human health: lessons from vitamin D receptor null mice. Endocr Rev. 2008;29:726-76.

11. Reichrath J. Vitamin D and the skin: an ancient friend, revisited. Experiment Dermatol. 2007;16:618-25.

12. Nagpal $\mathrm{S}, \mathrm{Na} \mathrm{S}$, Rathnachalam R. Noncalcemic actions of vitamin D receptor ligands. Endocr Rev. 2005;26:662-87.

13. Grant WB, Holick MF. Benefits and requirements of vitamin D for optimal health: a review. Altern Med Rev. 2005;10(2):94-111.

14. Bishoff-Ferrari HA, Giovannucci E, Willett WC, Dietrich T, Dawson-Hughes B. Estimation of optimal serum concentrations of 25-hydroxyvitamin $D$ for multiple health outcomes. Am J Clin Nutr. 2006;84(1):18-28.

15. Kriebitzsch C, Verlinden L, Eelen G, Tan BK, Van Camp M, Bouillon $R$, et al. The impact of $1,25(\mathrm{OH})_{2} D_{3}$ and its structural analogs on gene expression in cancer cells - A microarray approach. Anticancer Res. 2009;29(9):3471-83.

16. Chen P, Hu P, Xie D, Qin Y, Wang F, Wang H. Meta-analysis of vitamin D, calcium and the prevention of breast cancer. Breast Cancer Res Treat. 2009. Epub 2009 Oct 23. [Epub ahead of print]

17. Garlan CF, Gorham ED, Mohr S, Garland F. Vitamin D for cancer prevention: global perspective. Ann Epidemiol. 2009;19:468-83.

18. Wactawski-Wende J, Kotchen JM, Anderson GL, Assaf AR, Brunner RL, O'Sullivan MJ, et al. Calcium plus vitamin D supplementation and the risk of colorectal cancer. $\mathrm{N}$ Engl J Med. 2006;354:684-96.

19. Yin M, Wei S, Wei $Q$. Vitamin D receptor genetic polymorfisms and prostate cancer risk: a meta-analysis of 36 published studies. In J Clin Exp Med. 2009;2:159-175. 
20. Lou YR, Qiao S, Talonpoika R, Syvälä H, Tuohimaa P. The role of vitamin $\mathrm{D}_{3}$ metabolism in prostate cancer. J Steroid Biochem Mol Biol. 2004;92(4):317-25. Epub 2004 Dec 19.

21. Manolagas SC, Provvedini DM, Tsoukas CD. Interactions of 1,25-dihydroxyvitamin $D_{3}$ and the immune system. Mol Cell Endocrinol. 1985;43(2-3):113-22.

22. Bouillon $R$, Bischoff-Ferrari $H$, Willett W. Vitamin $D$ and health: perspectives from mice and man. J Bone Min Res. 2008;23(7): 974-79.

23. Grant WB. Epidemiology of disease risks in relation to vitamin $D$ insufficiency. Prog Biophys Mol Biol. 2006;92:65-79.

24. Svoren BM, Volkening LK, Wood JR, Laffel LM. Significant vitamin $D$ deficiency in youth with type 1 diabetes mellitus. J Pediatr. 2009;154(1):132-4.

25. Bener A, Alsaied A, Al-Ali M, Al-Kubaisi A, Basha B, Abraham A, et al. High prevalence of vitamin $D$ deficiency in type 1 diabetes mellitus and healthy children. Acta Diabetol. 2009;46(3):183-9.

26. Ponsonby AL, Pezic A, Ellis J, Morley R, Cameron F, Carlin J, et al. Variation in associations between allelic variants of the vitamin $D$ receptor gene and onset of type 1 diabetes mellitus by ambient winter ultraviolet radiation levels: a meta-regression analysis. Am J Epidemiol. 2008;168(4):358-65.

27. Mory DB, Rocco ER, Miranda WL, KasamatsuT, Crispim F, Dib SA. Prevalence of vitamin $D$ receptor gene polymorphisms Fokl and Bsml in Brazilian individuals with type 1 diabetes and their relation to beta-cell autoimmunity and to remaining beta-cell function. Hum Immunol. 2009;70(6):447-51.

28. Schuch NJ, Garcia VC, Martini LA. Vitamin D and endocrine diseases. Arq Bras Endocrinol Metab. 2009;53:625-33.

29. Johnson JA, Grand JP, Roche PC, Kumar R. Immunohistochemical localization of the $1,25(\mathrm{OH})_{2} \mathrm{D}_{3}$ receptor and calbindin D28k in human and rat pancreas. Am J Physiol. 1994;267:356-60.

30. Bland R, Markovic D, Hills CE, Hughes SV, Chan SL, Squires PE, et al. Expression of 25 hydroxyvitamin $D_{3}-1$ alpha-hydroxylase in pancreatic islets. J Steroid Biochem Mol Biol. 2004;89-90(15):121-5.

31. Norman AW, Frankel JB, Heldt AM, Grodsky GM. Vitamin D deficiency inhibits pancreatic secretion of insulin. Science. 1980;209:823-5.

32. Hypponen E, Power C. Vitamin D status and glucose homeostasis in the 1958 British birth cohort: the role of obesity. Diabetes Care. 2006;29:2244-6.

33. Gedik A, Akalin S. Effects of Vitamin D deficiency and repletion on insulin and glucagons secretion in man. Diabetologia. 1986;29:142-5.

34. Clark SA, Stumpf WE, Sar M. Effect of 1,25-dihydroxyvitamin $D_{3}$ on insulin secretion. Diabetes. 1981;30(5):382-6.

35. Maestro B, Campión J, Dávila N, Calle C. Stimulation by 1,25-dihroxyvitamin $D_{3}$ of insulin receptor expression and responsiveness for glucose transport in U-937 human promonocytic cells. Endocr J. 2000;47:383-91.

36. Scragg R, Sowers M, Bell C. Serum 25-hydroxyvitamin $D_{3^{\prime}}$ diabetes and ethnicity in the National Health and Nutrition Examination Survey. Diabetes Care. 2004;27:2813-8.

37. Forouhi NG, Luan J, Cooper A, Boucher BJ, Wareham NJ. Baseline serum 25-hydroxy Vitamin $D$ is predictive of future glycemic status and insulin resistance: the Medical Research Council Ely Prospective Study 1990-2000. Diabetes. 2008;57(10):2619-25.

38. Mattila C, Knekt P, Mannisto S, Rissanen H, Laaksonen MA, Montonen J, et al. Serum 25 hydroxyvitamin D concentration and subsequent risk of type 2 diabetes. Diabetes Care. 2007;30:2569-70.

39. Pitas AG, Dawson-Hughes B, Li T, Van Dam RM, Willett WC, Manson $\mathrm{JE}$, et al. Vitamin $\mathrm{D}$ and calcium intake in relation to type 2 diabetes in women. Diabetes Care. 2006;29:650-6.

40. Pedrosa MAC, Lazaretti-Castro M. Papel da vitamina $D$ na função neuromuscular. Arq Bras Endocrinol Metab. 2005;49:495-502.

41. Demay M. Muscle: a nontraditional 1,25-dihydroxyvitamin D target tissue exhibiting classic hormone-dependent vitamin $D$ receptor actions. Endocrinology. 2003;144(12):5135-7.

42. Bouillon R, Bischoff-Ferrari $H$, Willett. Vitamin $D$ and health: perspective from mice and men. J Bone Min Res. 2008;23(7):974-9.

43. Janssen HCP, Samson MM, Verhaar H. Vitamin D deficiency, muscle function, and fals in elderly people. Am J Clin Nutr. 2002;75:611-5.

44. Moreira-Pfrimer LD, Pedrosa MA, Teixeira L, Lazaretti-Castro M. Treatment of vitamin $D$ deficiency increases lower limb muscle strength in institutionalized older people independently of regular physical activity: a randomized double-blind controlled trial. Ann Nutr Metab. 2009;54(4):291-300.

45. Bischoff-Ferrari HA, Dawson-Hughes B, Staehelin HB, Orav JE, Stuck $A E$, Theiler $R$, et al. Fall prevention with supplemental and active forms of vitamin $D$ : a meta-analysis of randomized controlled trials. BMJ. 2009;339:b3692.

46. Sugiura $S$, Inaguma $D$, Kitagawa $A$, Murata $M$, et al. Administration of alfacalcidol for patients with predialysis chronic kidney disease may reduce cardiovascular disease events. Clin Exp Nephrol. 2010;14(1):43-50. [Epub 2009 Oct 31]

47. LiYC, Kong J, Wei M, Chen Z-F, Liu SO, Cao L-P. 1,25 dihydroxyvitamin $D_{3}$ is a negative endocrine regulator of renin-angiotensin system. J Clin Invest. 2002;110(2):229-38.

48. Brown AJ, Slatopolsky E. Vitamin D analogs: therapeutic applications and mechanisms for selectivity. Mol Aspects Med. 2008;29(6):433-52. Epub 2008 May 1. Review

49. Murphy PK, Wagner CL. Vitamin D and mood disorders among women: an integrative review. J Midwifery Womens Health. 2008;53(5):440-6.

50. Wilkins $\mathrm{CH}$, Sheline YI, Roe CM, Birge SJ, Morris JC. Vitamin D deficiency is associated with low mood and worse cognitive performance in older adults. Am J Geriatr Psychiatry. 2006;14(12): 1032-40.

51. Munger KL, Levin LI, Hollis BW, Howard NS, Ascherio A. Serum 25 hydroxyvitamin $D$ levels and risk of multiple sclerosis. JAMA. 2006;296(23):2832-7.

52. Hoogendijk WJ, Lips P, Dik MG, Deeg DJ, Beekman AT, Penninx BW. Depression is associated with decreased 25-hydroxyvitamin $\mathrm{D}$ and increased parathyroid hormone levels in older adults. Arch Gen Psychiatry. 2008;65(5):508-12.

53. Gombart A. The vitamin D-antimicrobial pathway and its role in protection against infection. Future Microbiol. 2009;4(9):1151-65.

54. Nnoaham KE, Clarke A. Low serum vitamin D and tuberculosis: a systematic review and meta-analysis. Int $\mathrm{J}$ Epidemiol. 2008;37:113-9. 